\title{
ALMEIDA, Djaimilia Pereira de. As telefones. Lisboa: Relógio d'água, 2020.
}

\section{Roberta Guimarães Franco}

Universidade Federal de Minas Gerais (UFMG), Belo Horizonte, Minas Gerais / Brasil

robertagfranco14@gmail.com

http://orcid.org/0000-0003-0098-2481

"Se fosse uma peça de teatro, haveria um telefone no palco e elas em cena, faladoras, mas surdas. Falariam uma com a outra, sem se ouvirem nem se responderem. Duas tagarelas surdas" (ALMEIDA, 2020, p. 27). A passagem citada resume, em muitos sentidos, a estrutura do último livro de Djaimilia Pereira de Almeida, jovem escritora, mas já consolidada pela crítica e pelas pesquisas acadêmicas. As telefones, publicado em maio de 2020, é o sexto livro da escritora que estreou em 2015 com a obra Esse cabelo.

Dando continuidade ao tema do trânsito entre Angola e Portugal, iniciado em 2015 com Esse cabelo e reiterado em 2017 com o romance Luanda, Lisboa, Paraíso, As telefones concentra-se agora em umuniverso familiar bastante restrito - a relação entre mãe e filha - mas igualmente fragmentado, como aqueles que compõem os livros anteriores: famílias divididas entre os dois países, por razões várias que desenham o cenário das migrações posteriores ao processo de descolonização angolana. $\mathrm{O}$ artigo no plural e no feminino "as", aplicado ao objeto substantivo masculino "telefone", delimita as protagonistas dessa história, mediada quase unicamente pelo contato telefônico, com raríssimos encontros presenciais, em Luanda ou em Lisboa.

Formado por pequenos capítulos, o livro de aproximadamente noventa páginas, apresenta os "diálogos" entre mãe e filha - Filomena e Solange - separadas já na primeira infância da menina, quando 
Filomena decide mandar a filha para Portugal, para ser criada por sua irmã, já que a fome e o desemprego, para além do cenário de guerra civil em Angola, a impediam de cuidar de si mesma e de Solange: "Depois veio fome, eh fome mesmo de verdade, tive de te mandar para a casa da tua tia Benedita, a minha irmã tinha casa bem posta, comida na mesa" (ALMEIDA, 2020, p. 29). Retomando a passagem citada como abertura desta resenha, e justificando o uso anteriormente de aspas na palavra "diálogos", a relação entre mãe e filha confere à narrativa inúmeros momentos de silêncio, afinal estamos diante de "faladoras / tagarelas surdas".

O silêncio também está presente na constante metáfora do desconhecimento do corpo alheio, que se desdobra no auto-desconhecimento. A filha Solange, uma das vozes narradoras de As telefones, anuncia, já na abertura do livro, a impossibilidade: "Não conheço o teu corpo, Filomena. Não conheço o meu corpo. De olhos fechados, não me lembro da tua cara. De olhos fechados, não sei como é a minha cara. Conhecemo-nos por telefone" (ALMEIDA, 2020, p. 9). A afirmação do desconhecimento, de um tipo de presença-ausente, será reiterada por Solange ao longo da narrativa, não conhecer a imagem da sua origem significa uma barreira intransponível para a construção do seu próprio caminho: "Não conheço o meu corpo porque não conheço o teu. [...] A cada instante, és para mim um vazio. Não sei com quem me pareço, como se a verdade fosse uma história sem princípio. Se não conheces o meu corpo, também não o conheço" (ALMEIDA, 2020, p. 19).

Embora o livro aborde a relação por meio da multiplicidade de vozes narrativas - ora a mãe, ora a filha e ainda há a presença de um narrador onisciente - é majoritariamente pela perspectiva de Solange que conhecemos a história de distância, de fragilidade, de raros encontros, mas sobretudo de persistência. A manutenção do elo entre mãe e filha só é possível pela fala que emprenha os ouvidos: "A distância entre nós, a morte. Para sobrevivermos, quando não estamos em linha, não existimos. O telefonema: uma ressureição semanal, seguida de nova escuridão. Habituámo-nos ao que as chamadas fizeram de nós. Emprenhámos pelos ouvidos" (ALMEIDA, 2020, p. 11); mas que como já vimos é também surda. Nesse sentido, a sobrevivência é sempre dúbia, não significa morrer, já que os batimentos, a respiração, estão lá, mesmo que ao longe por telefone, mas tampouco significa vida em seu sentido pleno, pois a falta de uma imagem que corporifique 
aquela mãe leva a uma inexistência: "Não existes a sério, nem quando estamos juntas. És a telefonista do abismo" (ALMEIDA, 2020, p. 49).

Diante desse jogo de sobrevivência, entre vida e morte, presença e ausência, existência e inexistência, cabe ao leitor igualmente o lugar de escuta, que justifica mais uma vez o título no feminino dado à obra. Complementando as brechas que a estrutura narrativa gera ao simular, em vários momentos, a conversa telefônica, ouvida apenas de um lado da linha, o leitor atravessa os pequenos capítulos dessa história de distância. Formado por pouquíssimos diálogos em discurso direto, Djaimilia utiliza a grafia em itálico para marcar os capítulos que correspondem à presença da mãe ao telefone, capítulos inteiros de uma conversa-monólogo, já que o leitor está diante apenas da fala de Filomena. Em fonte regular encontramos a narração de Solange, entrecortada em raros momentos pelo itálico da voz materna. Pertence ao narrador onisciente os incomuns momentos de encontro, observando mãe e filha nos passeios em Lisboa ou na vida doméstica em Luanda, como também em um dos momentos mais marcantes do livro, quando Filomena entrega à Solange os seus dentes de leite, guardados durante quase quarenta anos, como se guardasse o corpo da própria filha, ainda criança.

As telefones configura-se assim como uma narrativa que se insere em um projeto literário maior na produção de Djaimilia Pereira de Almeida, projeto voltado para essas vivências familiares, para o âmbito privado, entrecortado por uma história recente de migrações de um antigo império colonial. Vale lembrar, por exemplo, que a estrutura de capítulo-telefone, bem como a de capítulo-carta, também foi utilizada pela autora em Luanda, Lisboa, Paraíso, para assinalar aquela voz distante, da mãe e da esposa que ficou em Luanda enquanto marido e filho, Cartola e Aquiles rumaram para a antiga capital do Império. Para o leitor, mais uma peça desse complexo quebra-cabeças que é a história diaspórica e atlântica, no caso português e angolano extremamente recente, costurada aqui pelas distâncias que se aproximam por uma chamada telefônica. 


\section{Referência}

ALMEIDA, Djaimilia Pereira de. As telefones. Lisboa: Relógio d'água, 2020 . 